\title{
Applying Problem Based Learning Models Toward Theory Of Sets To Improve Problem-Solving Ability Of Students In Smp Negeri 1 Unggul Sukamakmur
}

\author{
${ }^{1}$ Nur Ainun, ${ }^{2}$ Almukarramah, ${ }^{3}$ Khairul Asri, ${ }^{4}$ Roslina \\ \{nurainun@serambimekkah.ac.id $\left.{ }^{1}\right\}$ \\ 1,3,4 Lecturer, Department of Mathematics Education, Faculty of Teaching and Education, \\ Universitas Serambi Mekkah, Banda Aceh, Indonesia \\ ${ }^{2}$ Lecturer, Department of Biology Education, Faculty of Teaching and Education, Universitas \\ Serambi Mekkah, Banda Aceh, Indonesia
}

\begin{abstract}
The study was aimed at collecting information of students' problem-solving abilities by using Problem Based Learning model. The study used experimental method with a quantitative approach. Data was processed and analyzed using quantitative statistics served by SPSS 16.0. Statistical analysis was carried out by pretest and posttest scoring, calculating means and standard deviations, measuring normality and homogeneity of pretest data sets as prerequisite for comparing two means, as well as scaling $\mathrm{N}$-gain and measuring the differences, and examining the interactions between learning factors of the students for their problem solving abilities. The study was conducted from April to November 2018 at SMP 1 Unggul Sukamakmur and Serambi Mekkah University. The results showed that: 1) the problem solving abilities of students after Jigsaw technique of cooperative learning is better than those with common (conventional) learning technique in comparison toward overall students; 2) the problem solving abilities of students after Problem Based Learning method is better than those with common (conventional) method in comparison toward student's groups; and 3) interactions presented between the application of both learning methods and grouping students for their problem solving abilities as of differentiation of results yielding from each groups toward the abilities.
\end{abstract}

Keywords: Problem Solving, Problem Based Learning, Sets.

\section{Introduction}

The National Education System as regulated by the Act Number 20/2003 sets the goal of Indonesian education as to create nation's next generations who are faithful and devoted, as well as virtuous, intelligent and creative. The goal is then applied into education curriculum. Somehow, Indonesia has just replaced the School Based Curriculum (KTSP) with the curriculum 2013. In accordance with the Ministerial Regulation of Education and Culture Number 68/2013, objective of the curriculum 2013 is to set up Indonesian youngsters to acquire ability to live either as individuals or citizens who are faithful, productive, creative, 
innovative, and affective and by any means are able to contribute to community, nation and state. The objective, however, is dissolved into several subjects for each education unit. Learning, as stipulated by Act Number 20/2003, is defined as the process of interaction between learners and educators and learning resources in a particular learning environment. Hence, learning process that is compatible to the curriculum 2013 is student centered active learning, the nature of contextual learning, and the textbook contains the learning materials and processes, the assessment methods as well as the expected competencies. According to the Ministerial Regulation of National Education Number 68/2013 concerning the SMP-MTS Curriculum, the allocation of mathematics learning time in class VII of junior high school is 5 hours per week. The National Council of Teachers of Mathematics [1]states the importance of learning mathematics as:

"... in this changing world, those who understand and can do mathematics will have significantly enhanced opportunities and options for shaping their futures. Mathematical competence open doors to productive futures. All Students should have the opportunity and the support necessary to learn significant mathematics with depth and understanding ".

That was to say that in the era of globalization anybody that is able to understand and solve the mathematics will have big chance and choices in shaping the future. Mathematical ability surely leads to productive future. Therefore, all students must have opportunity and fully support to learn mathematics in depth and full understanding. Standard mathematical skills to master are problem solving, reasoning and proof, communication, connections and representation [1].One of the objectives of learning mathematics (Directorate of Education Personnel, 2008: 19) is so that students are able to solve problems including the ability to understand problems, designing mathematical models and interpreting obtained solutions. [2]agreed that teaching problem solving to students is to train students to create decisions. Decisions are created after students collect appropriate information, analyze them, and then did understand the need to re-examine the results obtained. Among many studies on students' mathematical abilities, one to mention is the Program for International Students Assessment (PISA). PISA is a study carried out by the Organization for Economic Cooperation and Development (OECD) about the abilities of 15-year-old student's in math, reading and science. Specifically for math, PISA measures the mathematical literacy in terms of contents and processes.

SMP Negeri 1 Unggul Sukamakmur is one of the schools in Aceh Besar District. Revealed by observations and interviews with either mathematics teachers or students at SMP Negeri 1 Unggul Sukamakmur, the mathematics textbook used in learning was one published by the Ministry of Education and Culture. It was also understood that learning activities applied here are still centered on the teacher. Learning activities were also supported by circulating LKS (student's worksheets). The LKS, somehow, are list of problems to solve rather than steps to follow by students to define concepts. Sometimes, the problem was come with solution. Piaget (1972) in [3] though, states that mathematics is made (constructed) by children, neither found like rock nor received from others as gift. Mathematics is solved by students themselves, not found like a stone in yard or came as a gift. It was revealed that student learning outcomes was increased by $5.4 \%$ while the percentage of classical completeness was increased by $13 \%$. The increase came as results of monitoring on learning process in accordance with the implementation of learning plan [4]. Underlining the situation, it is here to understand how the teacher carrying out the learning process to guide students in finding concepts of mathematics. According to [5] every teacher has three main roles namely facilitator, source of learning and monitor toward student activities. The learning process is carried out so that learning becomes effective, efficient, and lead to the competencies to be achieved. Teachers should conduct 
learning process in accordance to conditions and needs of the students. Hence, teacher should facilitate students to connect mathematical concepts in order to solve problems.

As mention by Woolfolk (Hamzah, 2007: 134) problem solving ability is the ability of a student to use thinking process to solve problems through collecting facts, analyzing information, defining several alternative solutions, and choosing the most effective one. Students' problem solving abilities can be observed from the problem solving phases that they write down. According to [6]there are four phases in problem solving, which are:

1) Understanding The Problem

This phase includes identifying problem, analyzing problem, and interpreting information provided by the problem. Student had to write down what is already provided by the problem and what is to solve.

2) Devising a Plan

This phase required student to develop several strategies that might be used to solve the problem. The strategies that might be used are: a) drawing or modeling, b) searching for pattern, c) guessing and checking, d) creating tables or diagrams, e) trying to simplify the problem, and f) writing out equations.

3) Carrying Out the Plan

Student carried out the plan created in the previous phase by avoiding mistakes. If a student had already understood the plan, the teacher then had time to guide rest of the group who are still experiencing difficulties by providing scaffolding through questioning comfortably.

4) Looking Back

Student evaluated the solution to avoid mistakes in every single step provided to the plan so that the student was confident that the extent obtained is the solution to the problem. The student then wrote down the conclusion of the problem.

One of the learning models that can be used by teachers to facilitate students in learning mathematics is Problem Based Learning (PBL) model. [7] suggest that PBL is a learning model with such approach to authentic problem that enable students to formulate their own knowledge, develop higher skills and inquiry, fostering self-directed habits and increase selfconfidence. PBL can be understood as that in learning students are dealing with problems in which they are expected to learn critical thinking skills deeply through problem solving (Husnidar, et al, 2014: 75).

Learning program that is in line with Problem Based Learning models is expected to make learning environment more attractive to students and able to foster mathematical concepts so that students do not easily forget the learning material since the Problem Based Learning model reflects the real world in the process [8].

Problem Based Learning refers to constructivism, where students actively acquire knowledge and construct it themselves as the teacher facilitates students through various activities. The constructivist learning environment changes the focus from information disseminated by teachers, which led to students' passive role, into students' autonomy and reflection, which led to students' active role (Jacobsen, Eggen, Kauchak, 2009: 9). Cases in Problem Based Learning is developed from real-world cases that exist in student's surroundings so that they are able to gain primary knowledge from learning material through investigation and communication with other students since in doing the activities student collaborate with other students in small groups and present the results in larger groups so that students gain learning experience (Jacobsen, Eggen, Kauchak, 2009: 9).

Likewise, in order to create more interesting and responsive learning process for students in the classroom teachers are encourage to not only using the PBL learning model but also 
need to utilize learning media. Learning media is one of the components of communication to convey messages from teacher to students that serves to optimize the learning process (Criticos, 2006: 65). The position of the media in learning is quite decisive, therefore even though a teacher has mastered the material well and has used the right method in conducting the process, not using any media for learning process could led to not achieving learning objectives optimally [9].

Furthermore, Mohamad Nur stated in [10] that PBL consists of five phase which are presented in table 1 as below.

Table 1. Learning Syntax using Problem Based Learning adapted from Mohamad Nur

\begin{tabular}{|c|c|}
\hline Phase & Student Activities \\
\hline Phase I & understood the purpose of \\
\hline $\begin{array}{l}\text { Orientate } \\
\text { student to the } \\
\text { problem }\end{array}$ & $\begin{array}{l}\text { learning, the necessary logistics and } \\
\text { motivate to be actively involved in } \\
\text { problem solving activities. }\end{array}$ \\
\hline Phase II & Students learn to limit and organize tasks \\
\hline $\begin{array}{l}\text { Organize } \\
\text { students } \\
\text { learn }\end{array}$ & em at hand. \\
\hline $\begin{array}{l}\text { Phase III } \\
\text { Guiding the } \\
\text { investigation } \\
\text { of individuals } \\
\text { or groups }\end{array}$ & $\begin{array}{l}\text { Students collect the appropriate } \\
\text { information, conduct experiments in } \\
\text { search for explanations. }\end{array}$ \\
\hline $\begin{array}{l}\text { Phase IV } \\
\text { Develop and } \\
\text { present the } \\
\text { work }\end{array}$ & $\begin{array}{l}\text { Students plan and prepare appropriate } \\
\text { works such as group reports, and helping } \\
\text { them share the duties with their friend. }\end{array}$ \\
\hline $\begin{array}{l}\text { Phase V } \\
\text { Analyze and } \\
\text { evaluate } \\
\text { problem- } \\
\text { solving } \\
\text { process }\end{array}$ & $\begin{array}{l}\text { Students reflect on or evaluate their } \\
\text { investigation/problem-solving and the } \\
\text { processes they used for. }\end{array}$ \\
\hline
\end{tabular}

In regard to the above theory it can be concluded that PBL begins with the provision of problems which relate to the real world. Students are actively group to identify and analyze the problems, investigate and search for material related to the problem, and present the results of the discussion. Meanwhile, the teacher acted as a facilitator. PBL phases that are conducted systematically are projected to develop students' ability to solve problems and to achieve predetermined learning objectives. Taken the discussion into account then it is necessary to conduct a PBL learning process on theory of sets to improve the problem solving ability of seventh grade junior high school students. The learning process is carried out in accordance with the curriculum 2013 and the phases of PBL. Problem Based Learning consists of 5 phases. The whole phases are applied to the mathematics learning process to determine the steps of learning activities and are applied to student activities to determine the steps of finding the concept. Since it is believe that PBL learning is proper to apply in order to improve students' problem solving abilities accordingly a study on improving problem solving ability of students of SMP Negeri 1 Unggul Sukamakmur by using PBL learning model on theory of sets was conducted. 


\section{Methodology}

This study was an experimental study using a quantitative approach aimed at determining problem solving abilities of students after cast into PBL model. The variable observed was merely problem solving abilities. This study applied to two classes, the experimental class and the control class. Both classes were design under the Randomized Pretest-posttest Control Group Design in this way:

$\mathrm{R} \mathrm{O} \mathrm{X}_{1} \mathrm{O}$ (experimental class)

$\mathrm{R} \mathrm{O} \mathrm{X}_{2} \mathrm{O}$ (control class)

where:

$\mathrm{R}=$ random groups

$\mathrm{O}=$ Pretest/Posttest

$\mathrm{X}_{1}=\mathrm{PBL}$ learning model

$\mathrm{X}_{2}=$ conventional learning model

The population in this study was all students of class VII of SMP Negeri 1 Unggul Sukamakmur. Sample was determined by using purposive sampling technique. Only two classes was taken as sample out pf the whole class VII of SMP Negeri 1 Unggul Sukamakmur i.e. class VII-1 as the experimental class and class VII-2 as the control class - class that uses conventional learning model.

Data for this study will be collected as by:

1. testing the problem solving skills to find out the increase of students ability; and

2. questionnaire for student to determine responses to learning process provided by

PBL learning model.

Data will be analyzed by scoring pretest and posttest results, calculating means and standard deviations, examining differences in the mean of the pretest, testing the normality and homogeneity of $\mathrm{N}$-gain, testing the $\mathrm{N}$-gain means difference of overall of students, testing the $\mathrm{N}$-gain means difference of groups of students, and testing the interactions between learning factors and students grouping for problem solving abilities.

\section{Gain calculation}

To find out the increase of the problem solving ability in the two classes, an analysis of the results of the initial and final tests was carried out. The results were analyzed using the average normalized gain formula - suggested to be more effective by Hake in [11]- as:

where:

$$
\langle g\rangle=\frac{\langle \% \text { post }\rangle-\langle \% \text { pre }\rangle}{100 \%-\langle \% \text { pre }\rangle}
$$

$\langle g\rangle \quad$ : average normalized gain

$\langle \%$ pre $\rangle:$ the percentage of the average of pre-test scores

$\langle \%$ post $\rangle$ : the percentage of the average of post-test scores

Gain level criteria are as follows:

Tabel 2. Gain Level Criteria

\begin{tabular}{cl}
\hline $\begin{array}{l}\text { Gain Level } \\
\text { Criteria }\end{array}$ & Gain Level Classifications \\
\hline $\mathrm{G}>0,7$ & High \\
$0,3<\mathrm{g} \leq 0,7$ & Moderate \\
$\mathrm{g} \geq 0,3$ & Low \\
\hline
\end{tabular}




\section{Results And Discussion}

Data regarding students' problem-solving ability were obtained by comparing scores from initial test (pretest) and final one (posttest). The data collected by this study was include the pretest and posttest scores as well as $\mathrm{N}$-gain of the students abilities either in experimental class which taught by using PBL learning or in control class which taught by using conventional learning. The pretest was conducted to determine the initial ability of both classes before being treated separately using PBL model for the experimental one or using conventional one for the other. The posttest was set after the treatment has completely done to find out the increase of learning outcomes achievement for both classes. Statistical results which include means, standard deviation and number of students by learning models is presented in the table 3 below.

Table 3. Students' Problems Solving Ability regrading PBL Model: Test Results

\begin{tabular}{|c|c|c|c|c|c|c|c|}
\hline \multirow[t]{2}{*}{ Class } & \multirow[t]{2}{*}{$\mathrm{N}$} & \multirow[t]{2}{*}{ Test } & \multirow[t]{2}{*}{ Highest Score } & \multirow[t]{2}{*}{ Lowest Score } & \multirow{2}{*}{\multicolumn{2}{|c|}{ SD }} & \multirow[t]{2}{*}{ Var } \\
\hline & & & & & & & \\
\hline \multirow{3}{*}{ Experiment } & \multirow{3}{*}{18} & Pretest & 70 & 47 & 62,28 & 6,875 & 47,271 \\
\hline & & Postest & 96 & 75 & 86,44 & 6,609 & 43,673 \\
\hline & & Pretest & 70 & 46 & 58,71 & 6,27 & 39,314 \\
\hline Control & 21 & Postest & 96 & 62 & 81 & 6,213 & 37,3 \\
\hline
\end{tabular}

The table shows that the average (means) score of students' problem solving abilities yielding from the pretest of the experimental class was lower than of the control class. The means score of pretest of the experimental and the control classes consecutively are equal to 62.28 (standard deviation is 6.875) and 58.71 (standard deviation is 6.270). It also shows that the standard deviation of the experimental class is greater than of the control class.

Normalized gain ( $\mathrm{N}$-gain) defines as an index of improvement in learning outcomes (index of improvement on problem solving abilities). In order to determine appropriate statistical test to find out the difference of means, both normality and homogeneity of N-gain were tested previously. The tests were assisted by SPSS 17.0. The descriptive results of Ngain regarding students' problem solving abilities in the classes shows below.

Tabel 4. Students' N-gain in term of Problem Solving Ability

\begin{tabular}{|c|c|c|c|c|c|c|}
\hline Class & $\mathrm{N}$ & $\begin{array}{l}\text { Highe } \\
\text { st } \\
\text { Score }\end{array}$ & $\begin{array}{l}\text { Lowe } \\
\text { st } \\
\text { Score }\end{array}$ & $\bar{x}$ & SD & ar \\
\hline $\begin{array}{l}\text { Experime } \\
\text { ntal }\end{array}$ & 18 & 0,87 & 0,17 & 0,63 & 0,233 & $\begin{array}{r}0, \\
054\end{array}$ \\
\hline Control & 21 & 0,82 & 0,19 & 0,55 & 0,206 & $\begin{array}{c}0, \\
043\end{array}$ \\
\hline
\end{tabular}

Observing Table 4 it is known that the average N-gain for students' problem solving ability in the experimental class is 0.63 and in the control one is 0.55 therefore the means of the experimental class is higher than the other one. As shown in the table the standard deviation of the experimental and control classes respectively are 0.233 and 0.206 , so that the standard deviation of the experimental class is higher than the other one which can be interpreted as 
that the values of $\mathrm{N}$-gain of the experimental class students are spread out over a wider range compare to the other class. Considering $\mathrm{N}$-gain values, students in each class divided into three groups where all students in the class distributed quite evenly such as $30 \%$ in the highlevel group, $35 \%$ in the moderate-level group, and 35\% in the low-level group. T-test was used to find out the difference in the increase of students' problem solving ability.

Table 5. Average N-gain of Problem Solving Ability of Experimental and Control Classes

\begin{tabular}{ccc}
\hline Class & Group Level & Average N-Gain \\
\hline Experimental & High & 0,81 \\
& Moderate & 0,56 \\
& Low & 0,20 \\
Control & High & 0,80 \\
& Moderate & 0,53 \\
& Low & 0,15 \\
\hline
\end{tabular}

Based on Table 5, it is observed that the average N-gain of the Problem Solving ability of the experimental class for those in high-level group is better - the value is 0.81 - compare to the high-level group of the control class - the value is 0.80 . Meanwhile, the value for the medium-level group of the experimental class is 0.56 and of the control class is 0.53 . Thus, the value for the low-level group of the experimental class is better than of the control class with a ratio of 0.05 .

Summary of the interaction between learning factors and grouping of students on improving problem-solving skills shows in Table 6 below.

Table 6. Test of the Interaction between Learning Factors and Grouping of Students on Improving Problem-Solving Skills

\begin{tabular}{lccccr}
\hline Source & $\begin{array}{c}\text { Type III Sum } \\
\text { of Squares }\end{array}$ & Df & $\begin{array}{c}\text { Mean } \\
\text { Square }\end{array}$ & F & Sig. \\
\hline Corrected & $1.785^{\mathrm{a}}$ & 5 & .357 & 121.973 & .000 \\
Model & & & & & \\
Intercept & 8.043 & 1 & 8.043 & $2,75 \mathrm{E}+06$ & .000 \\
Learning & .000 & 0 &. &. &. \\
Group & 1.716 & 4 & .429 & 146.584 & .000 \\
Learning & .000 & 0 &. &. &. \\
Error & .097 & 33 & .003 & & \\
Total & 15.210 & 39 & & & \\
Corrected & 1.881 & 38 & & & \\
Total & & & & & \\
\hline
\end{tabular}

As shown in Table 6 , the value of Sig. at 0.701 is higher than significant level $\alpha=0.05$. It also shows that the group did not yielded significant results in term of the improvement of problem solving abilities as indicated by $\alpha>0.05$. Nonetheless, learning did yield significant results in term of increasing problem solving abilities with Sig value at $0.004<\alpha=0.05$. It is conclude that there is no mutual influence provided by the learning model regarding the student groups on increasing problem solving abilities. It is also concluded that there is no mutual influence provided by the learning model regarding student levels on increasing problem solving abilities.

To find out which groups do not differentiate their problem-solving abilities, a Scheffe test should be run. 
Table 7. Scheffe Test on Interaction of Problem Solving Ability

\begin{tabular}{|c|c|c|c|c|c|c|}
\hline \multirow{2}{*}{$\begin{array}{c}\text { (I) } \\
\text { Group }\end{array}$} & \multirow[t]{2}{*}{ (J) Group } & \multirow{2}{*}{$\begin{array}{c}\text { Mean Difference } \\
(\mathrm{I}-\mathrm{J})\end{array}$} & \multirow{2}{*}{$\begin{array}{l}\text { Std. } \\
\text { Error }\end{array}$} & \multirow[t]{2}{*}{ Sig. } & \multicolumn{2}{|c|}{ 95\% Confidence Interval } \\
\hline & & & & & Lower Bound & Upper Bound \\
\hline High & Moderate & $.28^{*}$ & .026 & .000 & .19 & .38 \\
\hline & Low & $.60^{*}$ & .031 & .000 & .49 & .71 \\
\hline Moder & High & $-.25^{*}$ & .028 & .000 & -.35 & -.15 \\
\hline ate & Low & $.34^{*}$ & .031 & .000 & .24 & .45 \\
\hline Low & High & $-.61^{*}$ & .043 & .000 & -.77 & -.46 \\
\hline & Moderate & $-.33^{*}$ & .042 & .000 & -.48 & -.18 \\
\hline
\end{tabular}

Based on results showed in Table 7 , it is concluded that the increase of problem solving abilities between high and moderate groups is equal, that is at 0.020. Comparing High and low groups is also yielded similar number. Else, the moderate and low groups also gave same number that is 0.031 . These results conclude that there is no significantly different among the groups with regard to the improvement of problem solving abilities. Furthermore, there is no any interaction between the learning model and the student group towards the improvement of mathematical problem solving.

\section{Conclusion}

Based on the aforementioned findings in this study, the following conclusions can be drawn:

1. The lowest score for problem-solving ability produced in pretest of the experimental and control classes respectively are 47 and 46 . While, the post-test produced score of 75 as the lowest for both classes;

2. based on the whole student, problem solving abilities of students exposed to PBL learning was increase more than those to conventional learning which is lecture method without involvement of students in an active and generative process;

3. based on student groups, problem solving abilities of students exposed to PBL learning was increase more than those to conventional learning which is lecturing method without involvement of students in an active and generative process;

4. There is no interaction between the implementation of learning models and grouping students toward students' problem solving abilities; and

5. Overall, students in the experimental class have a positive responds towards the implementation of PBL model and toward learning mathematics as well.

\section{References}

[1] NCTM, Principle and Standards For School Mathematics. Reston: VA: NCTM, 2000.

[2] W. Sanjaya, Strategi Pembelajaran Berorientasi Standar Proses. Jakarta: Rajawali Pers, 2010

[3] R. Reys, Helping Children Learn Mathematics, 10th ed. USA: John iley \& sons, 2012.

[4] K. Asri, "Pembelajaran Kontekstual Meningkatkan Prestasi Belajar Matematika Siswa Smp Negeri 1 Idi Rayeuk'," vol. 27, no. September, pp. 312-317, 2016.

[5] Marsigit, "Pengembangan Nilai-nilai Matematika dan Pendidikan Matematika sebagai Pilar Pembangunan Karakter Bangsa,” Semin. Nas. Pengemb. Nilai-NIlai dan Apl. dalam Dunia Mat. sebagai Pilar Pembang. Karakter Bangsa, pp. 0-12, 2011.

[6] G. Polya, "How to Solve It: A New Aspect of Mathematical Method," 1998.

[7] R. I. Arends, Learning to Teach, Translated into Bahasa by Drs. Helly Prajitno. Bandung: JICA 
Universitas Pendidikan Indonesia, 2007.

[8] Husna, "MENINGKATKAN HASIL BELAJARMATEMATIKA DENGAN PENERAPAN MODEL PROBLEM BASED LEARNING PADA MATERI PROGRAM LINIER SISWA DI KELAS X MARKETING 1 SMK NEGERI 1 MEULABOH TAHUN AJARAN 2015/2016," vol. 29, no. September, pp. 77-83, 2017.

[9] Tamarli, "PENGGUNAAN MEDIA GAMBAR DENGAN MODEL PEMBELAJARAN PROBLEM BASED LEARNING (PBL) UNTUK MENINGKATKAN KEMAMPUAN BERPIKIR KRITIS SISWA PADA PEMBELAJARAN PPKn MATERI HAK AZASI MANUSIA KELAS XI-2 SMA NEGERI SUKAMAKMUR ACEH BESAR,” vol. 28, pp. 3334, 2017.

[10] Rusmono, Strategi Pembelajaran dengan Problem Based Learning itu Perlu. Bogor: Ghalia Indonesia, 2012.

[11] H. Tamalene, "Pembelajaran Matematika Dengan Model CORE Melalui Pendekatan Keterampilan Metakognitif Untuk Meningkatkan Kemampuan Penalaran Matematis Siswa Sekolah Menengah Pertama," Master's Thesis UPI Bandung, 2010. 